\title{
Career Choice: Social Studies to Be or Not to Be Among Candidates of Unified Tertiary Matriculation Examination in Akwa Ibom State
}

\author{
Dr. (Mrs) Cecilia E. Okon \\ Department of Educational Foundations, Guidance and Counselling, Faculty of Education, University of Uyo
}

Uto l. Archibong

Institute of Education, University of Uyo, Uyo

\section{Doi:10.5901/ajis.2015.v4n1p417}

\begin{abstract}
The paper took a look at the contributory factors to the dwindling enrolment of Akwa Ibom State candidates of the Unified Tertiary Matriculation Examination (UTME) into the social studies education programme of the University of Uyo, Uyo. The sample of the study was one thousand and sixty-six respondents selected from thirteen preparatory study centres in Uyo Local Government Area. The researchers used Hat and Draw method to carry out the selection. Any candidate who picked 'Yes' from a small container was drawn and 'No' was rejected. The questionnaire/checklist entitled 'Career Choice Questionnaire (CCU)" had parts $A$ and B, with four and ten test statements respectively. The data were coded and simple percentage was used for analysis. The study revealed that interest, parental influence, peer influence, job expectation, admission requirement, role model, status of parent, coping, inspiration and motivation are contributory factors to the dwindling enrolment of candidates into the social studies education programme. Recommendations were made based on the findings of this study.
\end{abstract}

Keywords: Career choice, Unified tertiary matriculation examination

\section{Introduction}

As a reformatory school instruction, social studies is designed to equip learners with desirable attitudes, values, skills and knowledge for cohesive social existence in the Nigerian society. Mezieobi (2011) noted that social studies is a value laden course of instruction meant to equip the learner with the cognition, values, attitudes and functional skills to survive in a dynamic society, replete with sporadic changes in information, technology, values and knowledge. Social studies by nature is innovative, reformative, goal-oriented and environmental sensitive in that learners are to be largely confronted with the problems of man in the Nigerian society. At present, the teaching and research in social studies has dynamically progressed from primary to post primary schools, Colleges of Education and the universities where Doctoral programmes are run. The objectives of social studies at the tertiary level of education in Nigeria as reported by Mezieobi and Edinyang (2013) are :

(i) ... to inculcate skills for individual's survival and contribution to national development;

(ii) to develop productive high level manpower for national transformation and development;

(iii) to develop skills of creative reflective critical decision making on emerging environmental problems; ... p. 21.

The nature and objectives of social studies in Nigeria notwithstanding, evidence in recent years has revealed a dwindling enrolment of students into the tertiary social studies education programmes. The number of students aspiring to further their education in social studies in tertiary institutions cannot measure up with the number of students aspiring to further their education in other areas. Most students who study social studies education in tertiary institutions only study it because they are not 'fortunate' to gain admission into the programmes of their choice.

The importance of career aspiration in the life of an individual is significant because a meaningful and happy life depends on a choice of a suitable and acceptable career. A suitable and acceptable career is one that offers means of livelihood and enables the person to achieve satisfactory life ambition (Peter, 2004). Durojaiye (2004) was of the opinion that parents are now getting aware of the low level of employment in Nigeria, not due solely to lack of positions, but partly due to the fact that their children have not been equipped to enter such positions. Many parents want their children to take after their professional positions or want their children to take to certain other 'high' sounding careers not minding the fact that children want to take to other careers which they are likely to be more effective, competent and capable. The children may not like the chosen career or may not have interest, flare or aptitude for it, but at the same time dread the 
idea of opposing their parents' wish (Adana, 2004).

Fufunwa (1974) supported that parents have considerable influence on their children's education even up to the age of thirty or more. Fufunwa posited that Nigerian children depend on their parents for advice as long as they live. The father's profession influences the children's choice of career. Fufunwa compares father's profession with children's career choice and discovered that certain groups of profession such as medicine, law, engineering, and accounting are inherited from parents or very close relatives. Bernett (2009) from the study of career levels scale in relation to family background arrived at the conclusion that the father's profession is likely to influence the child's choice of career.

Lisack (2008) undertook a study in an Indian school. The findings of the study revealed that $32.8 \%$ of the students selected parents or other relatives as persons most useful to make career choice for them. Lisack pointed out that the school was second to the family in career preference factors. Roe (2007) observed that a child's early career preference is determined by the early reaction of parents towards such a child. Olayinka (2003) found that from the study of job aspirations and educational goals in Lagos (Nigeria) $76.2 \%$ of his respondents relied on the advice of parents and other family relatives for choice of career. Nochman (2000) maintained that family disciplinary measures influence the choice of occupation. Nochman stressed the fact that childhood experiences do not only contribute to differentiations in capacities but also move for occupational choice. The family is a very important factor in determining career preference. Nochman noted that a significant number of students said their parents fully expressed opinion about their professional preference.

Trice \& king (2001) in a study of decision making by students and parents about education found that situations where parents left decision to their children were very few. Stable career preferences may emerge as early as kindergarten. They found out that their career preferences primarily centered around interest. Research has shown that interest continues to play a vital and primary role in the selection or rejection of occupation of the child. A number of factors have been found to influence children's career aspirations. Such factors include gender, parental influence, socioeconomic status and early school experiences. The role of gender in individual's career aspiration has been given much attention (Wahl \& Blackhurst 2000). Danziger (1983) found that socio-economic background and parental expectation tend to influence girl children career aspiration and expectations, while ability, academic achievement and opportunity tend to influence boy children's career expectations. McMahen \& Pattern (2007) found that boy children demonstrated a greater awareness of jobs and industry and were more interested in work tasks and work conditions than were girl children, who appeared to be more concerned with work environment. Combining career and family life also has been found to be an influencing factor in girl children career aspiration.

Parents may influence their children's career aspiration in a number of ways. First, parents tend to act as career role model (Schulenberg, Vondrack Crouiter, 2004). Children tend to relate to parental occupations. Mullis \& Gerwhel (2008) found that students' career aspirations tend to match their parents' occupation. For example, students whose parents were in unskilled occupations tend to be more interested in realistic occupations, while those students whose parents were in professional occupations or skilled occupations tend to be more interested in artistic social or conventional occupations. Those findings highlighted the influence of parental role modeling on children's career aspirations.

Family socio-economic status may also affect parents' perceived efficacy and academic aspiration which may affect their children's engagement in career activities (Bandura, Barbaranelli, Caparara \& Pasbrelli 2001). Children from low socio-economic background may not have access to career resources and may not effectively utilize available resources as those from higher socio-economic background. As a result children may have the ability to achieve their career aspiration, but may not aspire to high expectations because they neither have perceived efficacy nor do they have adequate resources to achieve them.

Early school experiences may also influence students' career aspiration. Students' future educational and occupational aspirations may be affected by the attention they receive from their teachers. For example students who received greater amount of attention from their teachers were found to have higher career aspiration than their counterparts who did not (Watson, Quatman \& Edler, 2002). Hence the home background, learner's ability and school environment do play vital roles in the career aspiration of the individuals.

It has been observed by these researchers that there is a dwindling enrolment of students into the social studies education programme of the University of Uyo, Uyo. The question therefore is: what are the factors of dwindling enrolment of candidate of Unified Tertiary Matriculation Examination (UTME) into the social studies education programme of the University?

2. Hence the purpose of this study was to investigate and establish the factors responsible for declining enrolment of candidates in the social studies education programme of the University of Uyo, Uyo. 


\section{Research Question}

In order to guide this study, this research question was formulated: What are the contributory factors of dwindling enrolment of candidates into the social studies programme?

\section{Research Method}

The survey research design was employed for this study, because it aims at determining the nature of situation, as it exists at the time of investigation. It suits this particular study since it concerns itself with ascertaining and establishing the status quo, factors or pieces of information at the time of research, presenting such information as they are (Uche, 2013).

Uyo Local Government Area is one of the 31 Local Government Areas in Akwa Ibom state. Incidentally, Uyo is the state capital of Akwa Ibom State. The people are predominantly civil servants and politicians mingled with petty trading and farming. Since Uyo is a cosmopolitan town, there is a mixture of Christians, Muslims and African Traditional worshippers and majority of them are literate. Uyo has eleven political wards, sixty-six villages with one state constituency and one federal constituency. Because of its cosmopolitan nature, this research study will receive a fair representation from other Local Government Areas and even outside the state.

The population of this study consisted of all registered candidates in the thirteen government-approved Unified Tertiary Matriculation Examination preparatory study centers in Uyo Local Government Area.

The estimated population for the 2013/2014 Unified Tertiary Matriculation Examination candidates was four thousand and twenty six candidates (this number constituted only those candidates who registered for the UTME preparatory classes). The researchers used hat and draw method to carry out the selection. Equal number of options of Yes and No were dropped in a small carton. Any candidate who picked Yes was selected and No was rejected. Eighty two respondents were selected from each study centre; yielding a sample size of one thousand and sixty six (1066) participants.

The instrument for this work consisted of a questionnaire/checklist, titled Career Choice Checklist (CCC). The instrument had ten item statements that reflected reasons for choosing a career- parental influence, job expectation, peer influence, and so on. The instruments were validated by experts in Test, Measurements and Evaluation in the Department of Educational Foundations, Guidance and Counseling of the University Of Uyo, Uyo. Reliability was established by administering the instrument on other unsampled Local Government Areas and Cronbach's alpha reliability coefficient estimated at 0.74 was realized.

The researchers personally administered the instrument on the respondents in the evenings when they had contacts with their resource persons. This questionnaire/checklist was self completed. The exercise took about fourteen days and the retention rate was $100 \%$. The data were coded and analyzed using simple percentages. The summaries of the results are presented in the Table below 1.

\section{Results}

The research question for this study sought to establish the contributory factors of dwindling choice of social studies education among candidates of Unified Tertiary Matriculation Examination in Uyo LGA of Akwa Ibom State. Data were analyzed using simple percentage and the results are presented thus in Table 1

Table 1: Contributory factors to dwindling choice of social studies education among Unified Tertiary Matriculation Examination Candidates.

\begin{tabular}{|l|c|c|c|c|c|c|}
\hline & No. of Yes & $\%$ & No. of No & $\%$ & Total No. & Total \% \\
\hline Interest & 803 & 75 & 263 & 25 & 1066 & 100 \\
\hline Parental Influence & 925 & 87 & 141 & 13 & 1066 & 100 \\
\hline Peer Influence & 218 & 20 & 848 & 80 & 1066 & 100 \\
\hline Job Expectation & 339 & 32 & 727 & 68 & 1066 & 100 \\
\hline Admission Requirement & 569 & 53 & 479 & 47 & 1066 & 100 \\
\hline Role Model & 346 & 32 & 720 & 68 & 1066 & 100 \\
\hline Status of parents & 831 & 78 & 237 & 22 & 1066 & 100 \\
\hline Coping & 422 & 40 & 644 & 80 & 1066 & 100 \\
\hline Inspiration & 587 & 55 & 479 & 45 & 1066 & 100 \\
\hline Motivation & 497 & 47 & 569 & 53 & 1066 & 100 \\
\hline
\end{tabular}


The result on Table 1 shows that parental influence is the highest contributory factor to dwindling choice of social studies $(87 \%)$. This is followed by status of parents (78\%), interest (75\%), inspiration (55\%), admission requirement (53\%), motivation $47 \%$ and coping (40\%). Other lesser contributory factors are: job expectation (32\%), role model (32\%), and peer influence (20\%).

\section{Discussion of Findings}

The result of the study has indicated parental influence as the main reason for dwindling choice of Social Studies among Unified Tertiary Matriculation Examination candidates in Akwa Ibom State. Respondents overwhelmingly identified parental influence as the major factor (87\%). This finding is supported by Fafunwa (1974) who asserted that parents have considerable influence on their children's education even up to the age of thirty or more. Nigerian children depend on their parents for advice as long as they live. Also Olayinka (2003) identified parental influence on children's career aspiration. In the investigation $76.2 \%$ of the respondents relied heavily on the advice of parents and other family members for choice of career. This makes these candidates vulnerable.

Status of parents has been shown to be a factor of dwindling choice of social studies (78\%). This is not surprising because well placed professional parents would want their children to be what they (parents) are as children tend to match their parents' occupation. Children whose parents were in unskilled occupation tend to be more interested in realistic occupation, while those children whose parents were in professional or skilled occupations tend to be more interested in artistic social or conventional occupations (Mullis \& Gwel 2008).

Interest and inspiration have also been identified as major contributory factors to dwindling choice of social studies $75 \%$ and $55 \%$ respectively. The study indicated that candidates would love to study social studies but due to parental influence they would not choose the programme. This is supported by Durojaiye (2004) who opined that parents want their children to take to 'high' sounding careers such as medicine, law, engineering etc, not minding if these children have interest in them.

Admission requirement and motivation also show strong contributory factor to declining social studies choice $53 \%$ and $47 \%$ respectively. Once a candidate has entry requirement and is motivated, such a candidate is free to choose a career from many alternatives. Even though these candidates (respondents) possess admission requirement, parental influence may hinder their choice of social studies. Consequently they lack motivation from the family.

One of the conditions to qualify as a graduate of social studies education is to go on Teaching Practice exercise for at least twelve weeks in all (i.e. six weeks in the third year and six weeks in the fourth or final year). Many of the respondents dreaded this exercise. This could explain why coping with social studies programme had only $40 \%$.

Job expectation only $32 \%$, contribute to dislike of social studies programme. This could be the reason that Durojaiye (2004) opined that parents are now getting aware of the low level of employment in Nigeria. They prefer their children to be equipped to enter positions of high professional class. In an investigation carried out by Okon \& Archibong (2013), $78 \%$ of the students indicated interest in social studies and said "that social studies was good but would not give them a good job".

Role Model (32\%), explains that parents tend to influence their children's career aspiration because they tend to act as career role models (Shulenberg, Vondrack \& Crouiter 2004). Children tend to relate with parental occupation. The low percentage of model could have been caused by parents' influence not to choose social studies as a programme of study.

From this study peer influence (20\%) is an indication that age mates, class mates, friends, and others, may not play primary roles in career choice. This is because early school experiences may influence students' career aspiration. Students' future educational and occupational aspiration may be affected by individual attention they receive from their teachers. Students who were found to have received attention individually from their teachers had higher career aspirations than their counterparts who did not (Watson, Quatran \& Edler 2002).

\section{Conclusion/Recommendations}

This study has revealed that the factors contributing to dwindling enrolment of candidates into the social studies education programme of the University of Uyo, Uyo are interest, parental influence, peer influence, job expectation, admission requirement, role model, status of parents, coping, inspiration and motivation. In sum, based on findings of this study, the prospective undergraduates tend to have doubt regarding the high status of social studies. As mentioned earlier Okon and Archibong (2013) found in their study that students believed social studies was useful, but did not 
believe social studies would help them get a job.

Among the social sciences, young individuals seem to think of social studies as a low status programme of study. The present unemployment situation in Nigeria further heightens the case. Today, young people prefer to read courses that would enable them become self employed or better still, high sounding courses such as medicine, law, engineering, accountancy etc.

The choice of a wrong career leads to unhappiness, discontent and ultimate failure, for the occupation that a person follows is not merely a means of earning a livelihood but also a way of life. It is through one's choice of career that the individual tries to realize his needs for self enhancement and self-realization.

When young people are forced into programmes of study which they are not capable, not interested and lack the skill, they end up struggling for a place in an occupation (job) for which they are unsuitable. Hence they go through life frustrated - not finding a true place. As a result, they struggle without achieving much.

This paper therefore recommends that parents and other family members should allow their children to choose programmes of study which they are comfortable. This is because when the interest is there, they will make it both in school and outside school life.

At present social studies is only taught at the junior secondary school level. It should be introduced to the senior secondary school level because of its relevance to modern society. The present state of social developments need it, as limiting it to junior secondary school is not enough. The indiscipline it aims to correct among adults and youths is still very much with us. If social studies is extended to the senior secondary school, it will be of greater service in socializing incoming generation and in building a strong, united and progressive Nigeria. This will strengthen social studies as an important vehicle for a better understanding of the society, the diversity of its people and cultures notwithstanding.

\section{References}

Adana, B. (2004). Guidance \& counseling: The relevant to the evolving secondary educational system in Nigeria. Ife: University of Ife Press Ltd.

Bandura, A., Barbaranelli, C., Caparara, C. \& Pastorelli, C. (2001). Self-efficacy beliefs as sharper of children's aspirations and career trajectories. Children Development, 72(1), 187-207.

Barnett, S. A. (2009). Instinct and intelligence. Middlesex: Harmonds Worth Penguin Books Ltd.

Danzizer, N. (1983). Sex related difference in the aspiration of high school students. Sex roles 9, 683-694.

Durojaiye, M. D. (2004). Educational and occupational practice in Nigeria. West African Journal of Education 17(117), 115-120.

Fafunwa, A. B. (1974). History of education in Nigeria. London: George Allen Unwin Ltd.

Lisack, J. K. (2008). Parental behaviours towards first and second children. Genet psychology: Manoge ,49, 97-114.

Mezieobi, D. I. \& Edinyang, S. D. (2013). Social studies: An introduction. In S. D. Edinyang, D. I. Mezieobi and I. E. Ubi (Eds.), Selected issues in social studies education. Calabar : Maesot and Company.

Mezieobi, D. I. (2011). Social studies as an embodiment of civics education for sustainable national development. Nigerian Journal of Social Studies, 14(2), 123-134.

McMahon, M. \& Pattern, W. (2007). Gender differences in children and adolescent perceptions influences in their career aspiration development. The School Counselor, 44, 368-376.

Mullis, R. L. \& Gerwels, D. (2008). Stability among vocational interests among high school students. Adolescence, 33, 699-708.

Nochman, B. (2000). A childhood experience and vocational denistry and social work. Journal of Counselling, XVII (8), 170-185.

Okon, C. \& Archibong, U. (2013). Lesson Presentation: The perception of junior secondary school students and their achievement in social studies. Journal of Education and Practice, 4 (2), 20-25.

Olayinka, M. S. (2003). Job aspiration of youths in Lagos: West African Journal of Education XVII (1), 95- 114.

Peter, E. F. (2004). Factors which contribute to youths' occupational choice. Journal of Applied Psychology, 25, 30-42.

Roe, A. (2007). Early determinants of vocational choice. Journal of Counselling Psychology, IV, 212-217.

Schulenberg, J. E., Vondrack, F. W. \& Croutex, A. C. (2004). The influence of family in vocational development. Journal of Marriage and the family, 10, 129-143.

Trice, A.D. \& King, R. P. ( 2001). Stability of kindergarten children's career aspirations. Psychology Reports, 68, 1378.

Uche, R. (2013). Dropout Syndrome among girls in secondary schools and human resources development in Nigeria. Journal of Education and Practice, 4 (2), 25-30.

Wahl, K. H. \& Blackhurst A. (2000). Factors affecting the occupational and educational aspirations of children and adolescents. Professional School Counselling, 3, 367-374.

Watson, C. M., Quatman, T. \& Edler, E. (2002). Career aspiration of adolescence girls. Effects of achievement level, grade and single sex school environment sex role. Journal of Research, 5, 325-345. 
